International Journal of English Literature and Social Sciences
Vol-6, Issue-1; Jan-Feb, 2021

\title{
The balanced scorecard's evolution as a strategic mechanism at banking sectors
}

\author{
Bayad Jamal Ali ${ }^{1}$, Govand Anwar ${ }^{2}$
}

${ }^{1}$ Business Administration Department, Komar University of Science and Technology, Sulaimani 46001, Kurdistan Region - Iraq ${ }^{2}$ Department of Business Administration, College of Administration and Financial Sciences, Knowledge University, 44001 Erbil, Kurdistan Region, Iraq

Received: 19 Nov 2020; Received in revised form: 03 Jan 2021; Accepted: 01 Feb 2021; Available online: 26 Feb 2021 (C2021 The Author(s). Published by Infogain Publication. This is an open access article under the CC BY license (https://creativecommons.org/licenses/by/4.0/).

\begin{abstract}
As the current study has an empirical and impartial nature, a quantitative method was considered the best method for achieving the research objectives of the study. A quantitative technique applied in order to analyze the current study. Sample design refers to the procedure or method the researcher is willing to accept in choosing items for the sample. Research sample was selected using a procedure of random sampling and it was carried out in different banks. A total of 140 questionnaires were distributed, however 128 participants properly filled out the questionnaires. The study applied multiple regression analysis to measure the current study. The results show that internal process as balanced scored card has significant positive influence on strategic mechanism at 5\% level. The results show that internal process as balanced scored card has significant positive influence on strategic mechanism at 5\% level. The results show that organizational capacity as balanced scored card has significant positive influence on strategic mechanism at 5\% level. The results show that customer as balanced scored card has significant positive influence on strategic mechanism at 5\% level. Moreover, all beta value is higher than .001. The results show that nonfinancial incentives have a better impact on employee success because they encourage them to be more environmentally conscious. As a result, it is proposed that, in order to ensure environmental protection, nonfinancial initiatives be used in accordance with financial measures to enhance internal company processes. For example, rather than conventional initiatives that would persuade sustainable change, it is recommended that measures related to waste and utilization of specific resources be taken. The methodological results further highlight the importance of learning and development as a constant phase rather than a seasonal operation.
\end{abstract}

Keywords—balanced scorecard, strategic mechanism, banking sector, Kurdistan-Iraq.

\section{INTRODUCTION}

The viewpoint of structural theory has been broadly adopted in the social sciences in order to analyze social and institutional developments as well as their causes and implications (Long et al. 2020). Strategic management analysis focused on an interpretive aspect was also inspired by institutional theory (Anwar, 2016). Thus, by taking an institutional viewpoint, the analysis explores the technicalities of management strategies and seeks to research the social and cultural forces that form the mechanisms and complexities of transition. Literature on strategic management studies drawing on the institutional logic viewpoint traditionally based on the macro and meso levels; however, current literature emphasizes the relevance of the micro level (Kankaew, 2020). These experiments were designed to explain the complex contexts in which several ILs communicate. For example, Ali, (2020) analyzed political and administrative logic in the sense of performing arts, which shapes their viewpoint by using budgets in the two cases they adopted. They concluded that the real variables of the situation have an impact on organizations and become "especially vulnerable to certain logics and less so to others" (Abdullah, et al. 2017). In the meantime, Anwar \& Ghafoor, (2017) investigated 
competing ILs in a Swedish football organization and observed the situation-specific aspect of the manner in which corporate and sports ILs merge decision-making in specific situations. Other accounting researchers investigated how competing ILs communicate with other situations/contexts (Fan \& Hui, 2020).

In recent decades, some strategic management analysis has been based on case studies in diverse settings, but the bulk of these studies found the research 'story' to be merely a 'reference.' A 'place' where the strategic management is being analyzed or a 'context' against which researchers appear to classify samples to establish MA theories. However, recent exposure to circumstances shows that, more important than the context, more focus needs to be placed on the particulars of the situation. This assumes that the setting is not just the location or history, but should be the subject of the analysis. Furthermore, studies that take the perspective of the strategic management to examine the situated essence of strategic management activities consider to be formed at the level of the organizational sector. Afterwards, they research how rationality interacts with a real organization. This viewpoint is analogous to a vast number of existing research in the field of institutional philosophy. For example, (Anwar \& Balcioglu, 2016) stated that "institutional logics are conceived primarily as given, fixed and hardly evolving in their journey through organizations," while Ali, (2021) stated that ILs are "situated and fluid" and that ILs' present viewpoints are "inattentive to the places and periods in which order is shaped and logics run" (Faizova et al. 2020). They made assumptions about the institutional philosophy in which transitions (the dynamics of institutional theory) occur in ILs due to tensions and disputes between logic at the organizational level. On the other hand, Anwar, (2017) argued that the prevalent structural studies in strategic management lack a strong distinction between current and new frameworks and a basis for understanding how the structures form the behavior of the agents. It is important to show that it is the agents who really make up the systems. In comparison to the above-mentioned studies by Rafiq et al. (2020) and Anwar \& Qadir, (2017), which concentrated on field-level ILs and how they operate within particular organisations, the Demir et al. (2020) paradigm focused on specific agencies within organizations and how they form strategic management activities. However, the framework of Ecem et al. (2020) was criticized for not specifically recognizing the position of actors and the power of the organizational sector. In addition, recent research on the IL perspective have explored how multiple and conflicting ILs can contribute to "practical variance" (Anwar \& Shukur, 2015). These studies considered social orders arising from a network of interrelated logics at the level of society in general and at the level of organization in particular. Studies used to concentrate mainly on IL at the organizational level; however, recent calls have been made to explore how ILs work within individual organizations (Ievdokymov \& Zavalii, 2020).

\section{LITERATURE REVIEW}

The BSC was first presented at the Harvard Business School in the early 1990s by Robert Kaplan and David Norton. At the beginning of this century, BSC has been proposed as the basis for a "strategic management framework" that has been widely known and implemented around the world (Andavar $\&$ Ali, 2020). BSC has arisen as a result of the realization that one success metric alone is insufficient to capture the entire performance kit of the organization (Hameed \& Anwar, 2018). For example, financial metrics are often perceived to be "lagging performance indicators" due to the fact that these indicators "document the impact of decisions not as decisions are taken, but rather when the financial impact of such decisions materializes, which could be long after decisions have been taken" (Harguem, 2021). For example, Cokins \& Căpușneanu, (2020) argued that at a time when some managers and academic scholars were focused on financial measures, others said 'forget financial measures; boost operational measures such as cycle time and defect rates. The quarterly statements will be followed" (Anwar, 2017). Following this stimulus from both the profession and the academy, the BSC has arisen to allow managers to observe every company from four distinct viewpoints consumer perspective, internal business perspective, creativity and learning perspective and financial perspective. In addition, the four client, internal market, creativity and learning and financial viewpoints provide managers with responses to the following four fundamental questions: "How do consumers see us?" "What do we have to excel at?" "Will we change and build value?" and "How can we look at shareholders?" respectively (Fedushko et al. 2021). Referring to the above instruments, a number of researchers objectively investigated correlations (Qing-Rui et al. 2020) and disparities (Yeshitila et al. 2020) between TDB and BSC. For example, Bessire and Baker (2005) have critically examined the BSC and TDB in a positive manner. They concluded that there was complementarity between the two instruments. While the TDB sought to lay down reliable theoretical roots for its presumption, it did not necessarily devote sufficient attention to building consensus. In the other hand, though, the BSC has a complex and ambiguous view of the political dimension of management regulation, the BSC became generally more realistic, although it did not have a scientific basis. In the meantime, Bourguignon and his collaborators 
have studied "verbal and ideological theories that form the basis of both approaches" (Anwar, 2017). Their investigation has broadened the mainstream viewpoint with regard to PMS, which are usually carried out with regard to political and organizational significance, although ideological and perspectives have been largely overlooked. Furthermore, in the above study, the same authors analyzed in more depth the underlying ideological assumptions of the two methods. Their goal was to "explain the gaps between them and explore the degree to which the ideological assumptions are consistent with the local ideals of American and French culture" (Kelliher et al. 2020). The research paper argued that the main gaps between the two methods are likely to be illuminated by ideological assumptions.
The research indented to investigate the influence of the balanced scorecard's evolution as a strategic mechanism. To measure the current study, the researchers used four balanced scorecard perspectives (financial, internal process, organizational capacity and customer). Earlier mentioned balanced scorecard perspectives are independent factors in the current study on the other hand strategic mechanism at banking sector is dependent factor. A quantitative technique applied in order to analyze the current study. Sample design refers to the procedure or method the researcher is willing to accept in choosing items for the sample. Research sample was selected using a procedure of random sampling and it was carried out in different banks. A total of 140 questionnaires were distributed, however 128 participants properly filled out the questionnaires.

\section{RESEARCH METHODOLOGY}

\section{Conceptual framework}

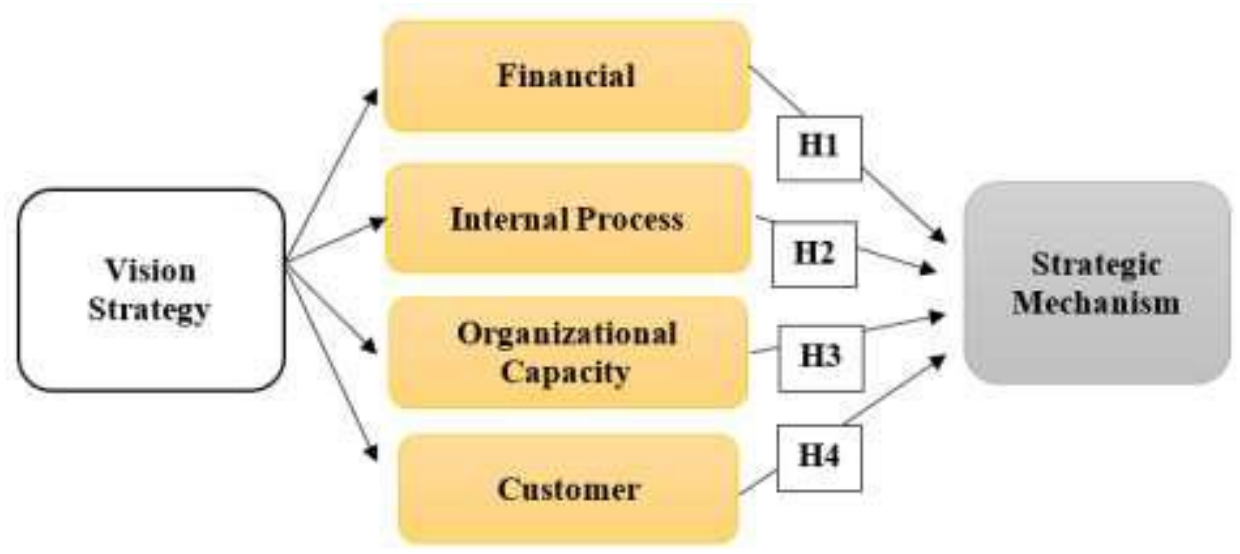

\section{Research Hypotheses}

Research hypothesis 1: Financial as balanced scorecard perspective influences significantly bank strategic mechanism.

Research hypothesis 2: Internal process as balanced scorecard perspective influences significantly bank strategic mechanism.

Research hypothesis 3: Organizational capacity as balanced scorecard perspective influences significantly bank strategic mechanism.

Research hypothesis 4: Customer as balanced scorecard perspective influences significantly bank strategic mechanism.

\section{Findings}

Table 1: Factor analysis- Observed Data Correlation Matrix

\begin{tabular}{|c|c|c|c|c|}
\hline Items & Financial & Internal process & Organizational capacity & Customer \\
\hline Financial & 1.00 & & & \\
\hline Internal process & .87 & 1.00 & & \\
\hline Organizational capacity & .62 & .68 & 1.00 & \\
\hline Customer & .41 & .43 & .51 & 1.00 \\
\hline
\end{tabular}


Table (1), demonstrates observed data correlation matrix which conducted by applying factors analysis for all variables (financial, internal process, organizational capacity and customer). The findings revealed that all variables' range between 0.001 to 1.00 this indicated that all factors are sufficient to be used to measure strategic mechanism.

Table 2: SAS PCA Output

\begin{tabular}{|l|l|l|l|l|}
\hline \multicolumn{5}{|c|}{ Eigenvalues of the Correlation Matrix: Total = 10 Average = 1 } \\
\hline Items & Eigenvalue & Difference & Proportion & Cumulative \\
\hline Financial & 2.01256876 & 0.328947350 & 0.2933 & 0.6291 \\
\hline Internal process & 2.67689526 & 1.54423985 & 0.3152 & 0.8121 \\
\hline $\begin{array}{l}\text { Organizational } \\
\text { capacity }\end{array}$ & 1.13265541 & 0.27032318 & 0.2151 & 0.9201 \\
\hline Customer & 0.86233223 & 0.10125212 & 0.0615 & 1.0000 \\
\hline
\end{tabular}

Table (2), demonstrates SAS PCA Output which conducted by applying factors analysis for all variables (financial, internal process, organizational capacity and customer). The findings revealed that all variables are sufficient to be used to measure strategic mechanism.

Table 3: Correlation Analysis

\begin{tabular}{|c|c|c|c|c|c|c|}
\hline \multicolumn{7}{|c|}{ Correlations } \\
\hline & & Financial & $\begin{array}{l}\text { Internal } \\
\text { process }\end{array}$ & $\begin{array}{l}\text { Organizational } \\
\text { capacity }\end{array}$ & Customer & $\begin{array}{l}\text { Strategic } \\
\text { mechanism }\end{array}$ \\
\hline \multirow[t]{3}{*}{ Financial } & Pearson Correlation & 1 & & & & \\
\hline & Sig. (2-tailed) & & & & & \\
\hline & $\mathrm{N}$ & 128 & & & & \\
\hline \multirow{3}{*}{$\begin{array}{l}\text { Internal } \\
\text { process }\end{array}$} & Pearson Correlation & $.398^{* *}$ & 1 & & & \\
\hline & Sig. (2-tailed) & .002 & & & & \\
\hline & $\mathrm{N}$ & 128 & 128 & & & \\
\hline \multirow{3}{*}{$\begin{array}{l}\text { Organizational } \\
\text { capacity }\end{array}$} & Pearson Correlation & $.417^{* *}$ & $.529^{* *}$ & 1 & & \\
\hline & Sig. (2-tailed) & .000 & .000 & & & \\
\hline & $\mathrm{N}$ & 128 & 128 & 128 & & \\
\hline \multirow[t]{3}{*}{ Customer } & Pearson Correlation & $.592^{* *}$ & $.478^{* * *}$ & $.493^{* *}$ & 1 & \\
\hline & Sig. (2-tailed) & .000 & .001 & .000 & & \\
\hline & $\mathrm{N}$ & 128 & 128 & 128 & 128 & \\
\hline \multirow{3}{*}{$\begin{array}{l}\text { Strategic } \\
\text { mechanism }\end{array}$} & Pearson Correlation & $.536^{* *}$ & $.601^{* *}$ & $.499^{* *}$ & $.611^{* *}$ & 1 \\
\hline & Sig. (2-tailed) & .000 & .000 & .000 & .000 & \\
\hline & $\mathrm{N}$ & 128 & 128 & 128 & 128 & 128 \\
\hline
\end{tabular}

As it can be seen in table (3), the correlation analysis between organizational learning (financial, internal process, organizational capacity and customer) as independent factors and strategic mechanism as dependent factor. The finding revealed that the value of Pearson correlation $(r=$
$.536^{* *}, \mathrm{p}<0.01$ ), between financial as balanced scored element and strategic mechanism this indicated that there is positive and strong correlation between financial as balanced scored element and strategic mechanism, the value of Pearson correlation $\left(\mathrm{r}=.601^{* *}, \mathrm{p}<0.01\right)$, between internal 
process as balanced scored element and strategic mechanism this indicated that there is positive and strong correlation between internal process as balanced scored element and strategic mechanism, the value of Pearson correlation $\left(r=.499^{* *}, \mathrm{p}<0.01\right)$, between organizational capacity as balanced scored element and strategic mechanism this indicated that there is positive and strong correlation between organizational capacity as balanced scored element and strategic mechanism, and the value of Pearson correlation $\left(r=.611^{* *}, \mathrm{p}<0.01\right)$, between customer as balanced scored element and strategic mechanism this indicated that there is positive and strong correlation between customer as balanced scored element and strategic mechanism.

Table 4: Multiple Regression Analysis

\begin{tabular}{|c|c|c|c|c|}
\hline Models & Fixed Effects Model & & & \\
\hline & & Coefficient & T-ratio & P-value \\
\hline \multirow{6}{*}{$\begin{array}{l}\text { Model } 1 \\
\text { (Financial) }\end{array}$} & Const & -36.6287 & -1.601 & 0.1111 \\
\hline & Beta & .549 & & .000 \\
\hline & Size & 4.45119 & 1.884 & $0.0612 *$ \\
\hline & $\operatorname{Adj} R^{2}$ & & 0.7511 & \\
\hline & F-Value & & $18.5378 * * *$ & \\
\hline & Durbin-Watson & & 2.9351 & \\
\hline \multirow{6}{*}{$\begin{array}{l}\text { Model } 2 \\
\text { (Internal Process) }\end{array}$} & Const & 15.3346 & 0.7224 & 0.471 \\
\hline & Beta & .601 & & .000 \\
\hline & Size & -0.234605 & -0.105 & 0.9165 \\
\hline & $\operatorname{Adj} R^{2}$ & & 0.7636 & \\
\hline & F-Value & & $19.7664 * * *$ & \\
\hline & Durbin-Watson & & 2.1236 & 0.8449 \\
\hline \multirow{6}{*}{$\begin{array}{l}\text { Model } 3 \\
\text { (Organizational Capacity) }\end{array}$} & Const & -5.03198 & -0.1959 & 0.6197 \\
\hline & Beta & .639 & & .000 \\
\hline & Size & 1.67627 & 0.6454 & \\
\hline & $\operatorname{Adj} R^{2}$ & & 0.7435 & \\
\hline & F-Value & & $17.8438 * * *$ & \\
\hline & Durbin-Watson & & 1.5361 & \\
\hline \multirow{6}{*}{$\begin{array}{l}\text { Model } 4 \\
\text { (Customer) }\end{array}$} & Const & -5.03198 & -0.1959 & 0.6197 \\
\hline & Beta & .501 & & .000 \\
\hline & Size & 1.67627 & 0.6454 & \\
\hline & $\operatorname{Adj} R^{2}$ & & 0.6871 & \\
\hline & F-Value & & $17.8438 * * *$ & \\
\hline & Durbin-Watson & & 1.5361 & \\
\hline
\end{tabular}

* significant at $0.10, * *$ significant at 0.05 and $* * *$ significant at 0.01 


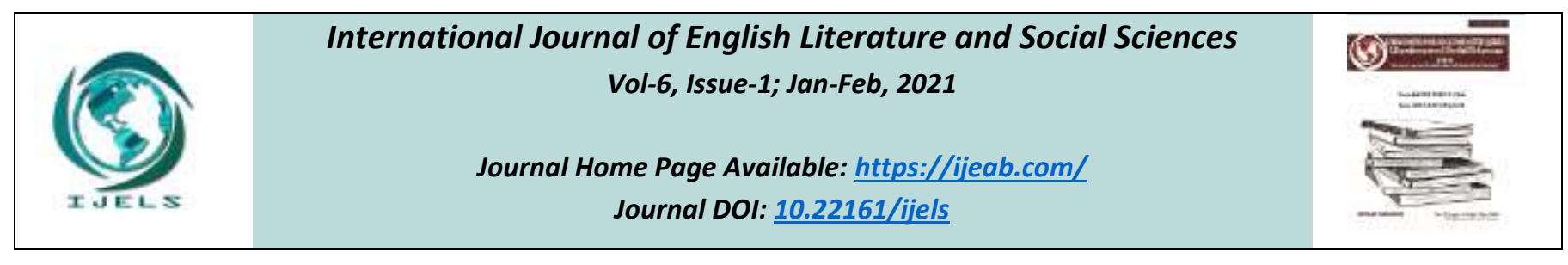

The results show that financial as balanced scored card has significant positive influence on strategic mechanism at $5 \%$ level. The results show that internal process as balanced scored card has significant positive influence on strategic mechanism at $5 \%$ level. The results show that internal process as balanced scored card has significant positive influence on strategic mechanism at 5\% level. The results show that organizational capacity as balanced scored card has significant positive influence on strategic mechanism at $5 \%$ level. The results show that customer as balanced scored card has significant positive influence on strategic mechanism at 5\% level. Moreover, all beta value is higher than .001 . All models have very high adjusted $R^{2}(0.7511$, $0.7636,0.7435$, and 0.6871 respectively) indicating the ability of the models explaining the variation of strategic mechanism due to variation of independent variables is very high. The F-value shows that the explanatory variables are jointly statistically significant in the model and the DurbinWatson (DW) statistics reveals that there is autocorrelation in the models.

\section{CONCLUSION}

The study examines the relationship between the balance scorecard perspectives and strategic mechanism at banking sector. The study applied multiple regression analysis to measure the current study. The results show that internal process as balanced scored card has significant positive influence on strategic mechanism at 5\% level. The results show that internal process as balanced scored card has significant positive influence on strategic mechanism at 5\% level. The results show that organizational capacity as balanced scored card has significant positive influence on strategic mechanism at 5\% level. The results show that customer as balanced scored card has significant positive influence on strategic mechanism at 5\% level. Moreover, all beta value is higher than .001 . All models have very high adjusted $\mathrm{R}^{2} \quad(0.7511,0.7636,0.7435$, and 0.6871 respectively) indicating the ability of the models explaining the variation of strategic mechanism due to variation of independent variables is very high. The F-value shows that the explanatory variables are jointly statistically significant in the model and the Durbin-Watson (DW) statistics reveals that there is autocorrelation in the models. The results show that non-financial incentives have a better impact on employee success because they encourage them to be more environmentally conscious. As a result, it is proposed that, in order to ensure environmental protection, non-financial initiatives be used in accordance with financial measures to enhance internal company processes. For example, rather than conventional initiatives that would persuade sustainable change, it is recommended that measures related to waste and utilization of specific resources be taken. The methodological results further highlight the importance of learning and development as a constant phase rather than a seasonal operation.

\section{RESEARCH LIMITATION AND FUTURE RESEARCH}

Similar to other studies, the thesis is limited by a few research limitations. One way to conduct prospective research projects is to consider the drawbacks. The first constraint is the sample size range. Since the analysis used a case-based survey, it's impossible to extrapolate the findings. Furthermore, since the energy market is capital intensive, it necessitates the addition of control variables such as political and regulatory variables in order to completely comprehend it. Future researchers can approach this problem with more variables in mind, such as political and regulatory issues, socio-cultural factors, and so on. Another weakness is something that has to do with the technique. Despite the fact that the research architecture has generalizability and empirical truth, there is still space for subjective exploration of the phenomenon. Since the BSC system is not yet completely developed in this case, it would be immensely useful to analyze the issue using a qualitative approach as well. Furthermore, the analysis involves the operationalization of environmental protection, although two other elements, economic and social dimensions, are unable to be operationalized due to time limitations and the nature of the research.

\section{REFERENCES}

[1] Long, H., Liu, H., Li, X., \& Chen, L. (2020). An Evolutionary Game Theory Study for Construction and Demolition Waste Recycling Considering Green Development Performance under the Chinese Government's Reward-Penalty Mechanism. International Journal of Environmental Research and Public Health, 17(17), 6303.

[2] Alia, B. J. Consumer attitudes towards healthy and organic food in the Kurdistan region of Iraq. Journal of Growing Science, 1-8.

[3] Anwar, K. (2016). Comparison between cost leadership and differentiation strategy in agricultural businesses. Custos E Agronegocio on Line, 12(2), 212-231. 
[4] Kankaew, K. (2020). The evolution of agribusiness management values from labor to brain mechanism that shape leadership style. In E3S Web of Conferences (Vol. 175, p. 13033). EDP Sciences.

[5] Ali, B. (2020). Impact of COVID-19 on Consumer Buying Behavior Toward Online Shopping in Iraq. Ali, BJ (2020). Impact of COVID-19 on consumer buying behavior toward online shopping in Iraq. Economic Studies Journal, 18(42), 267-280.

[6] Abdullah, M. S., Toycan, M., \& Anwar, K. (2017). The cost readiness of implementing e-learning. CUSTOS E AGRONEGOCIO ON LINE, 13(2), 156-175.

[7] Anwar, K., \& Ghafoor, C. (2017). Knowledge management and organizational performance: A study of private universities in Kurdistan. International Journal of Social Sciences \& Educational Studies, 4(2), 53.

[8] Fan, K., \& Hui, E. C. (2020). Evolutionary game theory analysis for understanding the decision-making mechanisms of governments and developers on green building incentives. Building and Environment, 179, 106972.

[9] Anwar, K., \& Balcioglu, H. (2016). The relationship between transformational leadership characteristics and effectiveness: A case study of construction companies in Erbil. International Journal of Science Technology and Management, 5(2), 250-256.

[10] Ali, B. J. (2021). Impact of consumer animosity, boycott participation, boycott motivation, and product judgment on purchase readiness or aversion of Kurdish consumers in Iraq. Journal of Consumer Affairs.

[11] Faizova, S. O., Ivanova, M. I., Faizova, O. L., Smiesova, V. L., Parshyna, O. A., \& Zavhorodnia, O. O. (2020). Use of Balanced Scorecard for Enterprise Competitiveness Assessment. J. Advanced Res. L. \& Econ., 11, 349

[12] Anwar, K. (2017). The Role of Effective Leadership in Crisis Management: Study of Private Companies in Kurdistan. Qalaai Zanist Scientific Journal, 2(4), 326-338.

[13] Ali, B. J. (2021). Assessing (The impact) of advertisement on customer decision making: Evidence from an educational institution. Ali, BJ (2021). Assessing (The impact) of advertisement on customer decision making: Evidence from an educational institution. Afak for Science Journal, 6(01), 267-280.

[14] Rafiq, M., Zhang, X., Yuan, J., Naz, S., \& Maqbool, S. (2020). Impact of a balanced scorecard as a strategic management system tool to improve sustainable development: measuring the mediation of organizational performance through PLS-smart. Sustainability, 12(4), 1365.

[15] Anwar, K., \& Qadir, G. H. (2017). A Study of the Relationship between Work Engagement and Job Satisfaction in Private Companies in Kurdistan. International Journal of Advanced Engineering, Management and Science, 3(12), 239944.

[16] Demir, A., Maroof, L., Khan, N. U. S., \& Ali, B. J. (2020). The role of E-service quality in shaping online meeting platforms: a case study from higher education sector. Journal of Applied Research in Higher Education, 128
[17] Ecem Yildiz, A., Dikmen, I., \& Talat Birgonul, M. (2020). Using system dynamics for strategic performance management in construction. Journal of Management in Engineering, 36(2), 04019051.

[18] Anwar, G., \& Shukur, I. (2015). the impact of recruitment and selection on job satisfaction: Evidence from private school in Erbil. International Journal of Social Sciences \& Educational Studies, 1(3), 4-13.

[19] Ievdokymov, V., \& Zavalii, T. (2020). Conceptual framework of a balanced scorecard: a value-oriented approach. Fundamental and applied researches in practice of leading scientific schools, 37(1), 17-26.

[20] Anwar, G., \& Shukur, I. (2015). Job satisfaction and employee turnover intention: A case study of private hospital in Erbil. International Journal of Social Sciences \& Educational Studies, 2(1), 73.

[21] Andavar, V., \& Ali, B. (2020). Rainwater for Water Scarcity Management: An Experience of Woldia University (Ethiopia). ANDAVAR, V., ALI, BJ, \& ALI, SA (2020). Rainwater for Water Scarcity Management: An Experience of Woldia University (Ethiopia). The Journal of Business Economics and Environmental Studies, 10(4), 29-34.

[22] Hameed, A. A., \& Anwar, K. (2018). Analyzing the Relationship between Intellectual Capital and Organizational Performance: A Study of Selected Private Banks in Kurdistan. International Journal of Social Sciences \& Educational Studies, 4(4), 39.

[23] Anwar, G., \& Shukur, I. (2015). The Impact of Training and Development on Job Satisfaction: A Case Study of Private Banks in Erbil. International Journal of Social Sciences \& Educational Studies, 2(1), 65

[24] Harguem, S. (2021). A Conceptual Framework on IT Governance Impact on Organizational Performance: A Dynamic Capability Perspective. Academic Journal of Interdisciplinary Studies, 10(1), 136-136.

[25] Cokins, G., \& Căpuşneanu, S. (2020). Management Accounting: The Sustainable Strategy Map and Its Associated Sustainability Balanced Scorecard. In Management Accounting Standards for Sustainable Business Practices (pp. 1-26). IGI Global.

[26] Anwar, K. (2017). Analyzing The Conceptual Model Of Service Quality And Its Relationship With Guests'satisfaction: A Study Of Hotels In Erbil. The International Journal of Accounting and Business Society, 25(2), 1-16.

[27] Fedushko, S., Peráček, T., Syerov, Y., \& Trach, O. (2021). Development of Methods for the Strategic Management of Web Projects. Sustainability, 13(2), 742.

[28] Qing-Rui, X. U., Zheng-Rong, C. H. E. N., \& Hua-Bin, W. U. (2020). Dynamic Analysis of Strategic Innovation in Traditional Manufacturing Enterprises-A Case Study Based on Haier Group. DEStech Transactions on Social Science, Education and Human Science, (icssm).

[29] Yeshitila, D., Kitaw, D., Jilcha, K., \& Muchie, M. (2020). Situational and Mixed Business Strategy Analysis for Market Competitiveness: An Exploration in Context of Africa. International Journal of Global Business and Competitiveness, 15(2), 106-120. 
[30] Anwar, K. (2017). Leading Construction Project Teams: The Effectiveness of Transformational Leadership in Dynamic Work Environments in Kurdistan. International Journal of Advanced Engineering, Management and Science,3(10), 239925

[31] Kelliher, F., Murphy, M., \& Harrington, D. (2020). Exploring the role of goal setting and external accountability mechanisms in embedding strategic learning plans in small firms. Journal of Small Business and Enterprise Development. 